\title{
DEVELOPING WRITING MATERIALS IN RECOUNT TEXT FOR THE EIGHT GRADE STUDENTS AT SMP RK SERDANG MURNI LUBUK PAKAM
}

\author{
AN ARTICLE \\ Submitted in Partial Fulfillment of the Requirements \\ for the Degree of Sarjana Pendidikan
}

By:

SRI AGUS TURNIP

Registration Number: 2133321061

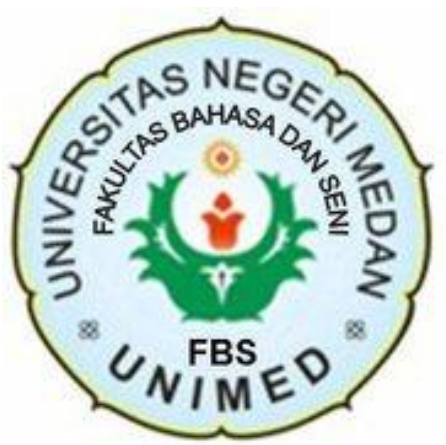

ENGLISH AND LITERATURE DEPARTMENT

FACULTY OF LANGUAGES AND ARTS

STATE UNIVERSITY OF MEDAN

2018 


\section{ARTIKEL}

\section{DEVELOPING WRITING MATERIALS IN RECOUNT TEXT FOR THE EIGHT GRADE STUDENTS AT SMP RK SERDANG MURNI LUBUK PAKAM}

Disusun dan Diajukan oleh:

Sri Agus Turnip

NIM. 2133321061

Telah diverifikaasi dan dinyatakan memenuhi syarat untuk diunggah pada jurnal online

Medan, Juni 2018

Menyetujui

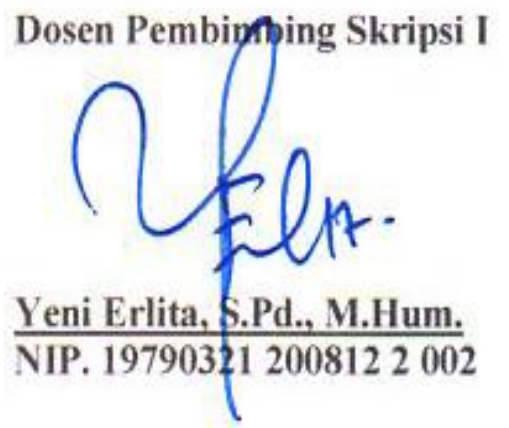

Dosen Pembimbing Skripsi II

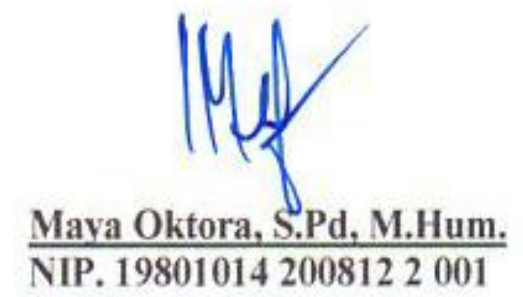

Ka. Program Studi

Pendidikan Bahasa Inggris

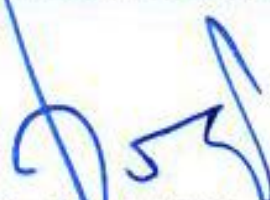

Nora Ronita Ddwi, S.Pd., S.S., M.Hum.

NIP. 198005222008122003 


\author{
DEVELOPING WRITING MATERIALS IN RECOUNT TEXT \\ FOR THE EIGHT GRADE STUDENTS AT SMP RK \\ SERDANG MURNI LUBUK PAKAM \\ *Sri Agus Turnip \\ ** Yeni Erlita \\ $* *$ Maya Oktora
}

\begin{abstract}
The objectives of this study was to develop the writing materials in recount text for the eight grade students at SMP RK Serdang Murni Lubuk Pakam. This was a Research and Development (R\&D) study. The subjects of the study were the students of eighth grade of SMP RK Serdang Murni Lubuk Pakam. The research procedures, were adapted from Jolly and Bolitho's model in Tomlinson (1998) with some modifications, consisting of conducting the need analysis, writing the course grid, developing the first draft, getting expert judgment and evaluating the first draft, also revising the first draft of the materials. The instruments to collect the data were need analysis questionnaire and expert judgment questionnaire. The data from the need analysis were analyzed quantitatively using frequency and precentage, then the results were used to develop the course grid. The data from the expert judgment were analyzed quantitatively through descriptive statistics while the suggestions were used to revise the first draft of the materials. The product of this study is a set of writing materials of recount text entitled "Guide for Writing" for students of eighth grade of SMP RK Serdang Murni Lubuk Pakam. The writing material is "My Unforgettable Experience". It consists of Pre-writing, Drafting, Responding, and Editing tasks ranging 15 tasks. Based on the research findings from the expert judgment, the whole aspects of the developed materials were 3.76 which was in the range of $3.25<\mathrm{x} \leq 4$ and can be categorized as "very good".
\end{abstract}

Keywords: Recount Text, Writing Materials, R\&D Method

\footnotetext{
*Graduate Status
}

***Lecturer Status 


\section{INTRODUCTION}

\section{Background of the Study}

Language is the medium through which students learn various concepts and skills, form their identities, and interact socially with others. Language is also the corner stone of the teaching and learning process (Bloom, et al., 2004). Students often think that communication is only being built from spoken language. It can be said that they can communicate in English if they have ability in speaking. In fact, communication also can be created by written language.

Writing as a communication device is not only the reason why writing is important to learn. Raimes (1983) indicates that writing can help our students for those reasons; firstly writing reinforces the grammatical structures, idioms and vocabulary that we teach, secondly when students write, they have a chance to be adventurous with the language to take risks, and lastly they become very involved with the new language; the effort to express ideas. There are many writing forms, some are creative, and some are not. However, all writing is creative writing because writing uses the materials of language, experiences, knowledge, textual sources, personal ideas and imaginings of the writer, bringing out something that did not exist before. Raimes (1983: 3) proposes the most important reason writing helps students learn. Why writing is important. He mentions that: First, writing reinforces student's grammatical structure, idioms and vocabulary. Second, when students write, they have a chance to express what they have already learnt. Third, students become involve in new language when they are writing. They will discover something new to write or a new way to express their ideas.

According to syllabus grade eight of junior high school the students should be able to write a recount text based on the daily life context. However, students' writing competence is relatively low. Based on the researcher's observation in SMP RK Serdang Murni Lubuk Pakam, students of the eight grade of SMP RK Serdang Murni Lubuk Pakamhave some problems related to their writing skill. First, students get problem in developing their ideas in writing a text. They feel 
confused to start writing and in the middle of writing process they do not know what they have to do to continue. Second, they found difficulties in choosing the words that suitable for their writing because they have lack of vocabulary. The other problem is the use of grammar. They feel confused dealing with the use of grammar. They are not being able to make a text in correct sentences. They still have some mistakes in using the grammar. In arranging sentences, they still have some mistakes in the use of punctuation, spelling and capitalization.

Among the four skills of learning English, writing is considered the most difficult skills to learn because students have to put their own ideas, develop their ideas, how to arrange their ideas into good sentences, how to make their writing cohesion and coherence, etc. Bell and Burnaby in Nunan (1989: 36) state that writing is considered as a complex activity because writers have to control content, format, sentence structure, vocabulary, punctuation, spelling and letter formation.

Materials are one of the ways to develope students' writing ability. The use of suitable materials will help students to learn writing in a good way. In the teaching-learning process, teachers have to develop the appropriate materials for students to encourage them to improve their ability in writing. However, the use of materials in the classroom is not interesting for students. Students feel bored to do the assignments because it only write the recount text by answering the questions from the texts. It does not give students a motivation to write based on what they are interested to write about. Therefore, it is necessary for the teacher to design interesting materials. The materials should provide students' needs and interest. Materials are useful to make students easier to catch the subject.

In Indonesia, English is the foreign language that is taught in school. In the eighth grade, students have many activities in writing some kinds of text. The standard of competences of writing texts which should be mastered by eighth grade students are responding the meaning of short functional texts and simple 
essays in the form of descriptive, recount, and narrative texts in daily life context. In this research, the researcher will be focus on recount text.

Based on explanation above, it is necessary to provide suitable and interesting materials for students of the eighth grade of SMP RK Serdang Murni Lubuk Pakam to encourage them to practice writing. The researcher interested to develop writing materials in recount text for students of the eighth grade of SMP RK Serdang Murni Lubuk Pakam.

\section{REVIEW OF LITERATURE}

English is divided into two skills; they are productive skills and receptive skills. One of productive skills in English teaching-learning process is writing. There are some definitions of writing according to some experts. Brown (2000: 335) assumes that written language is like spoken language, the difference between them is in graphics instead of auditory signals. Written language called the graphic representation of spoken language.

According to BNSP, curriculum is a set of plans and arrangements regarding objectives, content and learning materials as well as the means used as a guideline organization of learning activities to achieve objectives of the study. The aim of curriculum KTSP is to develop students' potential in the different areas, condition and local potential. The development of Curriculum KTSP based on national standards of education is to achieve the goals of national education. There are eight national education standards, they are standard of content, standard of process, competence of graduates, staff, facilities and infrastructure, management, financing and educational assessment.

There are some definitions of materials development. Graves (2000: 149) defines material development is the planning process of creating units and lessons to achieve the goal and objective of the study. It also can be defined as the process of creating, choosing or adapting, and organizing materials and activities until the 
students can achieve the objective to help them in reaching the goals of the courses.

Tomlinson (1998: 2) states materials development refers to anything to provide sources of language input and to exploit those sources in ways which maximize the like hood of intake.

In developing materials, there are some steps that should be followed. Jolly and Bolitho in Tomlinson (1998: 98) propose some steps that should be followed in developing writing materials. Those are:

a. Identification of need for materials

The first step is identification of need for materials. In this step, materials developers identify a need to fulfill or problem to solve.

b. Exploration of need

The second step is exploration of needs. The materials developers need to explore the area of needs or problems in term of the appropriateness of the language and function.

c. Contextual realisation of materials

The third step is contextual realisation of materials. The contextual realisation involves the suitable ideas, contexts and text.

d. Pedagogical realisation of materials

The fourth step is pedagogical realisation of materials. The pedagogical realisation involves the appropriateness of the exercises and activities and the appropriateness of the instruction.

e. Production of materials

The fifth step is production of materials. The physical production of the materials is designed in the form of the book including the layout, type size, and cover.

f. Evaluations of materials

The last step is evaluation of materials by a validator. The validator give comments with the worksheet. 


\section{RESEARCH METHODOLOGY}

The objective of this research is to develop writing materials for students of the eighth grade of SMP RK Serdang Murni Lubuk Pakam. These materials will be developed based on the students' needs. This research is categorized as an Educational Research and Development (R\&D). Gall and Borg (2003: 569) state that "Educational $\mathrm{R} \& \mathrm{D}$ is an industry-based development model in which the findings of research are used to design new products and procedures, which systematically field-tested, evaluated, and refined to meet the specified criteria of effectiveness, quality or similar standards". The result of this study will be writing materials for students of eighth grade of SMP RK Serdang Murni Lubuk Pakam. The research procedures of the research will be adapted from Jolly and Bolitho (in Tomlinson, 1998) with some modifications. There are 5 steps of the research procedures which were conducting needs analysis, writing the course grid, developing the first draft of the materials, getting expert judgment and revising the first draft of the materials.

\section{Techniques of Analysis Data}

The data of this study was the need for students of eight grade at SMP RK Serdang Murni Lubuk Pakam. The data analyzed by getting the solution of the students 'problem and the appropriate English writing materials particularly recount text. The data was analyzed as follows: Analyzing students' needs by using questionnaire. The data was needed to evaluate the existing writing materials and analyze the students needs. Then the researcher developed the relevant speaking materials based on needs analysis. 
DATA ANALYSIS AND RESEARCH FINDINGS

Data Analysis:

\section{NEED ANALYSIS}

Students' Opinions of Writing

\begin{tabular}{|l|l|c|}
\hline \multicolumn{1}{|c|}{ Questios } & \multicolumn{1}{|c|}{ Options } & Percentage (\%) \\
\hline \multirow{4}{*}{$\begin{array}{l}\text { In my opinion, writing a } \\
\text { text in English is an } \\
\text { activity that.... }\end{array}$} & Very easy to do & $1.1 \%$ \\
\cline { 2 - 3 } & Easy to do & $20.2 \%$ \\
\cline { 2 - 3 } & Quite easy to do & $28.4 \%$ \\
\cline { 2 - 3 } & Hard to do & $\mathbf{5 3 . 4 \%}$ \\
\cline { 2 - 3 } $\begin{array}{l}\text { In my opinion, writing } \\
\text { is...... }\end{array}$ & Very hard to do & $6.8 \%$ \\
\cline { 2 - 3 } & Important & $33 \%$ \\
\cline { 2 - 3 } & Quite Important & $\mathbf{4 2 \%}$ \\
\cline { 2 - 3 } & Not important & $25 \%$ \\
\hline \multirow{3}{*}{$\begin{array}{l}\text { Text } \\
\text { T....... write an English }\end{array}$} & Always & $0 \%$ \\
\cline { 2 - 3 } & Often & $1.1 \%$ \\
\cline { 2 - 3 } & Sometimes & $11.4 \%$ \\
\cline { 2 - 3 } & Never & $\mathbf{7 2 . 7 \%}$ \\
\hline
\end{tabular}

The Respondents Necessities

\begin{tabular}{|l|l|c|}
\hline \multicolumn{1}{|c|}{ Question } & \multicolumn{1}{|c|}{ Options } & Percentage (\%) \\
\hline \multirow{2}{*}{$\begin{array}{l}\text { Which skills do you need } \\
\text { in writing an English } \\
\text { text? }\end{array}$} & $\begin{array}{l}\text { Using the suitable } \\
\text { structure and words } \\
\text { choice. }\end{array}$ & $\begin{array}{l}\text { Expressing ideas into } \\
\text { some different sentences. }\end{array}$ \\
\cline { 2 - 3 } & $\begin{array}{l}\text { Arranging the appropriate } \\
\text { sentences based on the }\end{array}$ & $45.5 \%$ \\
\hline
\end{tabular}




\begin{tabular}{|l|l|c|}
\hline & function each text. & \\
\cline { 2 - 3 } & $\begin{array}{l}\text { Arranging jumbled } \\
\text { paragraphs into a genre } \\
\text { text }\end{array}$ & $45.5 \%$ \\
\cline { 2 - 3 } & $\begin{array}{l}\text { Using the correct and } \\
\text { appropriate grammar }\end{array}$ & $50 \%$ \\
\hline & Others. & $0 \%$ \\
\hline
\end{tabular}

The Respondents Lacks

\begin{tabular}{|c|l|c|}
\hline \multicolumn{1}{|c|}{ Question } & \multicolumn{1}{|c|}{ Options } & Percentage \\
\hline \multirow{5}{*}{$\begin{array}{l}\text { When writing an English } \\
\text { text, I have difficulties in }\end{array}$} & $\begin{array}{l}\text { Arranging the structure of } \\
\text { the sentences. }\end{array}$ & $\begin{array}{l}\text { Formulating sentences } \\
\text { based on the function } \\
\text { each text. }\end{array}$ \\
\cline { 2 - 3 } & $\begin{array}{l}\text { Selecting the appropriate } \\
\text { word choice }\end{array}$ & $45.5 \%$ \\
\cline { 2 - 3 } & $\begin{array}{l}\text { Expressing ideas. } \\
\text { correct structure of the } \\
\text { text. }\end{array}$ & $51.1 \%$ \\
\cline { 2 - 3 } & $\begin{array}{l}\text { Using the correct and } \\
\text { appropriate grammar. }\end{array}$ & $39.8 \%$ \\
\cline { 2 - 3 } & Others & $\mathbf{6 1 . 4 \%}$ \\
\hline
\end{tabular}

The Respondents Wants

\begin{tabular}{|c|c|c|}
\hline Question & Options & Percentage (\%) \\
\hline \multirow{4}{*}{$\begin{array}{l}\text { My desire after learning } \\
\text { writing, to make me.... }\end{array}$} & $\begin{array}{l}\text { To increase my ability } \\
\text { in writing English. }\end{array}$ & $73.9 \%$ \\
\hline & $\begin{array}{l}\text { To enable me to master } \\
\text { vocabularies. }\end{array}$ & $48.9 \%$ \\
\hline & $\begin{array}{l}\text { To enable me to use the } \\
\text { suitable vocabularies in } \\
\text { writing. }\end{array}$ & $36.4 \%$ \\
\hline & $\begin{array}{l}\text { To increase my } \\
\text { knowledge of text types }\end{array}$ & $48.9 \%$ \\
\hline
\end{tabular}




\begin{tabular}{|l|l|c|}
\hline & $\begin{array}{l}\text { To enable me to master } \\
\text { grammar in writing. }\end{array}$ & $45.5 \%$ \\
\cline { 2 - 3 } & $\begin{array}{l}\text { To enable me to write } \\
\text { with right conjunction }\end{array}$ & $23.9 \%$ \\
\cline { 2 - 3 } & $\begin{array}{l}\text { To enable me writing the } \\
\text { text as studied before }\end{array}$ & $20.5 \%$ \\
\cline { 2 - 3 } & Others & $1.1 \%$ \\
\hline
\end{tabular}

The Topic of Materials

\begin{tabular}{|l|l|c|}
\hline \multicolumn{1}{|c|}{ Question } & \multicolumn{1}{|c|}{ Options } & Percentage (\%) \\
\hline The topic of input $\begin{array}{l}\text { } \\
\text { material that I like is } \\
\text { related to.... }\end{array}$ & Daily life & $10.2 \%$ \\
\cline { 2 - 3 } & Social & $48.9 \%$ \\
\cline { 2 - 3 } & Teenager & $23.9 \%$ \\
\cline { 2 - 3 } & Education & $15.9 \%$ \\
\cline { 2 - 3 } & Science & $13.2 \%$ \\
\cline { 2 - 3 } & Political, Economic, \\
& Social and Cultural & $0 \%$ \\
\cline { 2 - 3 } & Others & \\
\hline
\end{tabular}

The Input of Materials

\begin{tabular}{|l|l|c|}
\hline \multicolumn{1}{|c|}{ Question } & \multicolumn{1}{|c|}{ Options } & Percentage (\%) \\
\hline The material input that I & Picture & $\mathbf{6 3 . 6 \%}$ \\
\cline { 2 - 3 } like is.... & Written text & $35.2 \%$ \\
\cline { 2 - 3 } & Video & $44.3 \%$ \\
\cline { 2 - 3 } & Comic-strip & $27.3 \%$ \\
\cline { 2 - 3 } & Others & $0 \%$ \\
\hline
\end{tabular}

The Lengths of Input

\begin{tabular}{|l|l|c|}
\hline \multicolumn{1}{|c|}{ Question } & \multicolumn{1}{|c|}{ Options } & Percentage (\%) \\
\hline The number of words that & $\mathbf{1 0 0 - 2 0 0}$ words & $\mathbf{6 4 . 8 \%}$ \\
\cline { 2 - 3 } I want in the text is..... & $200-300$ words & $22.7 \%$ \\
\hline
\end{tabular}




\begin{tabular}{|l|l|c|}
\hline & $300-400$ words & $6.8 \%$ \\
\cline { 2 - 3 } & $400-500$ words & $5.7 \%$ \\
\cline { 2 - 3 } & $>500$ words & $0 \%$ \\
\hline
\end{tabular}

The Importance of Grammar

\begin{tabular}{|l|l|c|}
\hline \multicolumn{1}{|c|}{ Question } & \multicolumn{1}{|c|}{ Options } & Percentage (\%) \\
\hline $\begin{array}{l}\text { Do the comprehension of } \\
\text { grammar needed in } \\
\text { writing English text? }\end{array}$ & Yes & $\mathbf{9 7 . 7 \%}$ \\
\cline { 2 - 3 } & No & $2.3 \%$ \\
\hline
\end{tabular}

The Importance of Text Type

\begin{tabular}{|l|l|c|}
\hline \multicolumn{1}{|c|}{ Question } & \multicolumn{1}{|c|}{ Options } & Percentage (\%) \\
\hline $\begin{array}{l}\text { Is the comprehension of } \\
\text { text type important in } \\
\text { writing text? }\end{array}$ & Yes & $\mathbf{9 5 . 5 \%}$ \\
\cline { 2 - 3 } & No & $4.5 \%$ \\
\hline
\end{tabular}

The Learning Procedure

\begin{tabular}{|l|l|c|}
\hline \multicolumn{1}{|c|}{ Question } & \multicolumn{1}{|c|}{ Options } & Percentage (\%) \\
\hline \multirow{4}{*}{$\begin{array}{l}\text { In writing, I want activity } \\
\text { like... }\end{array}$} & Writing text from the picture & $30.7 \%$ \\
\cline { 2 - 3 } & Writing text by given the topic & $\mathbf{4 5 . 5 \%}$ \\
\cline { 2 - 3 } & Free writing. & $43.2 \%$ \\
\cline { 2 - 3 } & $\begin{array}{l}\text { Making mindmapping before } \\
\text { writing. }\end{array}$ & $11.4 \%$ \\
\cline { 2 - 3 } & Writing as the comic-strip. & $15.9 \%$ \\
\cline { 2 - 3 } & Writing with questions as guide. & $21.6 \%$ \\
\cline { 2 - 3 } & Others & $1.1 \%$ \\
\hline
\end{tabular}




\section{Setting}

\begin{tabular}{|l|l|c|}
\hline \multicolumn{1}{|c|}{ Question } & \multicolumn{1}{|c|}{ Options } & Percentage (\%) \\
\hline \multirow{2}{*}{$\begin{array}{l}\text { In doing writing } \\
\text { activities, I like doing.... }\end{array}$} & Individually & $\mathbf{6 9 . 3 \%}$ \\
\cline { 2 - 3 } & In pairs & $11.4 \%$ \\
\cline { 2 - 3 } & Group & $30.7 \%$ \\
\hline
\end{tabular}

Teacher and Learner Roles

Learners' Role

\begin{tabular}{|l|l|c|}
\hline \multicolumn{1}{|c|}{ Questions } & \multicolumn{1}{c|}{ Options } & Percentage (\%) \\
\hline \multirow{2}{*}{$\begin{array}{l}\text { In the teaching learning } \\
\text { process, I want to study } \\
\text { by.... }\end{array}$} & Asking friends & $28.4 \%$ \\
\cline { 2 - 3 } & Critical thinking & $25 \%$ \\
\cline { 2 - 3 } & Given the materials & $30.7 \%$ \\
\cline { 2 - 3 } & Discussion & $\mathbf{6 0 . 2 \%}$ \\
\cline { 2 - 3 } & Others & $2.3 \%$ \\
\hline
\end{tabular}

Teacher's Role (During Writing Activity)

\begin{tabular}{|l|l|c|}
\hline \multicolumn{1}{|c|}{ Questions } & \multicolumn{1}{|c|}{ Options } & Percentage (\%) \\
\hline $\begin{array}{l}\text { During the teaching and } \\
\text { learning process, you } \\
\text { would like the teacher } \\
\text { to.... }\end{array}$ & $\begin{array}{l}\text { Explaining the } \\
\text { materials. }\end{array}$ & $\mathbf{6 3 . 6 \%}$ \\
\cline { 2 - 3 } & Giving many examples. & $48.9 \%$ \\
\cline { 2 - 3 } & Discussion. & $46.6 \%$ \\
\cline { 2 - 3 } & Others & $0 \%$ \\
\hline
\end{tabular}

Teacher's Role (When Students Have Difficulties)

\begin{tabular}{|c|c|c|}
\hline Questions & Options & Percentage $(\%)$ \\
\hline \multirow{2}{*}{$\begin{array}{l}\text { When you have } \\
\text { difficulties in } \\
\text { writing a text, the teacher } \\
\text { should do }\end{array}$} & $\begin{array}{l}\text { Explaining the materials } \\
\text { Again }\end{array}$ & $60.2 \%$ \\
\hline & $\begin{array}{l}\text { Answering questions } \\
\text { directly }\end{array}$ & $23.9 \%$ \\
\hline
\end{tabular}




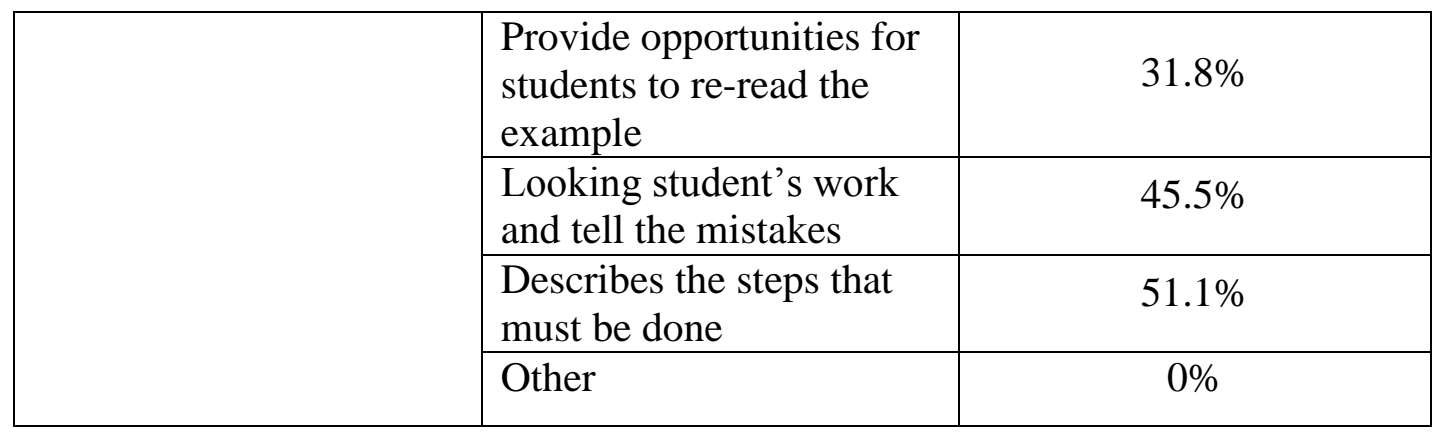

Teachers' Role (After Writing Activity)

\begin{tabular}{|l|l|c|}
\hline \multicolumn{1}{|c|}{ Questions } & \multicolumn{1}{c|}{ Options } & Percentage (\%) \\
\hline $\begin{array}{l}\text { After finishing the task } \\
\text { (writing text), the } \\
\text { teachershould do... }\end{array}$ & $\begin{array}{l}\text { Giving correction and } \\
\text { providing signs on your } \\
\text { mistakes that you have } \\
\text { made. }\end{array}$ & $\mathbf{7 0 . 5 \%}$ \\
\cline { 2 - 3 } & $\begin{array}{l}\text { Giving correction on } \\
\text { your } \\
\text { mistakes that you have } \\
\text { made directly. }\end{array}$ & $47.7 \%$ \\
& $\begin{array}{l}\text { Giving correction on } \\
\text { your } \\
\text { mistakes that you have } \\
\text { made in the forum. }\end{array}$ & $26.1 \%$ \\
\cline { 2 - 3 } & Others & $0 \%$ \\
\hline
\end{tabular}

\section{MATERIAL DEVELOPMENT}

The Framework of the Developed Materials 


\section{UNIT TITLE}

\section{PRE-WRITING}

1. Input: a text as an example of the genre of the text.

2. The information about the generic structure of the text.

3. Grammar Zone: information about grammar is used of the text.

\section{DRAFTING}

Activities for students to practice their writing skill and to apply the understanding about the materials given before.

\section{RESPONDING}

Activities for students to give and get feedbacks from peers and the teacher.

\section{EDITING}

Activity for students to write their final draft.

\section{COMPLEMENT}

1. My dictionary (Word List)

2. Reflection

3. Summary

4. Glossary

\section{English Writing Material}

The materials were developed into one unit. It is conducted in four stages. The first was Pre-writing. In this stage, students were introduced the text given to the students as a model. The researcher also gave the information about generic structure and the genre of the text to the students. Several questions about the text were also given to guide them in comprehending about the content of the text. They also were given the information about grammar and some activities to practice their grammar.. 


\section{MATERIAL VALIDATION}

The Score of Expert Judgment on English Speaking Materials

\begin{tabular}{|l|l|l|l|}
\hline No & Aspect & Expert & Category \\
\hline 1 & Content & 4 & Very Good \\
\hline 2 & Language & 3,83 & Very Good \\
\hline 3 & Presentation & 3,22 & Good \\
\hline 4 & Graphic & 4 & Very Good \\
\hline & Total & 3,76 & Very Good \\
\hline
\end{tabular}

\section{REVISION AND FINAL PRODUCT}

\section{Revision of Product}

\begin{tabular}{|l|l|l|}
\hline \multicolumn{1}{|c|}{$\begin{array}{c}\text { Point of the } \\
\text { Unit }\end{array}$} & \multicolumn{1}{|c|}{ Point to Revise } & \multicolumn{1}{c|}{ Revision } \\
\hline Content & $\begin{array}{l}\text { 1. Add guided task. } \\
\text { 2. Change the text. }\end{array}$ & $\begin{array}{l}\text { 1. Guided task is added. } \\
\text { 2. The text is changed. }\end{array}$ \\
\hline Language & $\begin{array}{l}\text { 1. There are still some } \\
\text { Grammatical mistakes. }\end{array}$ & 1. Correct the mistakes. \\
\hline Presentation & 1. No revision & 1. No revision \\
\hline Graphic & $\begin{array}{l}\text { 1. Change the color of } \\
\text { the background. }\end{array}$ & $\begin{array}{l}\text { 1. The color of the } \\
\text { background is changed. }\end{array}$ \\
\hline
\end{tabular}

\section{CONCLUSIONS AND SUGGESTIONS}

\section{Conclusions}

Based on the research findings, the needs analysis are divided into two aspects which are the target needs and the learning needs. Those aspects are described below.

\section{a. The Target Needs}

Based on the research findings, the needs analysis are divided into two aspects which are target needs and learning needs. Those aspects are described below:

1) More than a half of students $(53.4 \%)$ state that writing is difficult to do. 
2) There are $42 \%$ of the students say that writing is an important skill and $33 \%$ of them say that writing is very important.

3) Most of the students (72.7\%) sometimes practice their writing activity.

4) More than a half of students (63.6\%) choose the skill that they need in writing a text is using the suitable structure organization and words choice.

5) More than a half of students (61.4\%) agree that they have lack of grammar.

6) Most of the students (73.9\%) claim they want to increase their ability in writing English.

\section{b. The Learning Needs}

Based on the results of the needs analysis, the learning needs are listed below:

1) in terms of input, more than a half of the students (67\%) want the topic of materials related to daily life. For input of materials, $63.6 \%$ of students want pictures as the input before writing. Regarding the input length, most of students (64.8\%) want to have input texts with 100-200 words in length. Most of students also (97.7\%) state that the comprehension of grammar is important. $95.5 \%$ of students said that the comprehension of text type was important.

2) In terms of writing procedure, almost a half of the students (45.5\%) want to write text by given the certain topic.

3) Related to the setting, more than a half of students (69.3\%) want to do writing activities individually.

4) In terms of students' role, most of students (60.2\%) want to study by discussion.

5) In terms of teacher' roles, most of the students $(63.6 \%)$ like the teacher explains the materials during writing activities. $60.2 \%$ of the students like if the teacher explains the materials again when they have difficulties in writing 
activity. Most of students (70.5\%) like after finishing the task; they want the teacher give them corrections and provides signs on the students' mistakes.

Based on the expert judgment, the developed materials can be categorized as appropriate. The developed materials have the characteristics as described in this following paragraph.

The first part of this unit is the picture of the unit. The title of the unit is related to the students' life, It is My Unforgettable Experience. Then, it is followed by some questions related to the topic.

The main parts of this unit are divided into four stage. The first is Pre-Writing. The activities are designed to build students' background knowledge. Students are introduced to the genre of the text in the unit. Students are also given some activities to have comprehension about the generic structure of the text and the grammar used of the text. The second is Drafting. In this stage, students have to implement what they learnt in the previous to write their first draft of the text. The third is Responding. These activities are designed to make the students' writing better. In this stage, students' writing gets a feedback from the teacher or peers. The last stage is Editing. In this activity, students write their text after getting feedback from the teacher and peers.

The last part is complement including reflection, the summary of the unit and my dictionary.

\section{Suggestions}

The final product of this research is writing materials in recount text for students of eighth grade of SMP RK Serdang Murni Lubuk Pakam. Considering the research findings, there are some suggestions proposed for some parties.

\section{The English Teachers}

The English teachers of eighth grade of junior high school who teach English could use the developed materials in the teaching learning process. These developed materials accomplish to improve the students' writing skill. The teacher could use the developed materials to teach the students about recount text. 


\section{The Other Material Developers}

The most important thing in developing materials is conducting students' needs analysis. The product of the research should provide students' needs and interest. The developed materials are very useful for the teachers and the students in the teaching learning process if they are easily used. The next thing that should be considered by the developers is the design of the materials. The design of the materials should be eye-catching and interesting for the students.

\section{REFERENCES}

Alamargot, Denis and Chanquoy, Lucile. 2001. Through the Models of Writing. Kluwer Academic Publishers.

Alyani. 2016. Developing Writing Materials by Using Genre Based Approach for the First Semester of the Tenth Grade Students at SMA PIRI 1 Yogyakarta. Yogyakarta : Yogyakarta State University.

Arias. 2008. Educational Implications of The Theoretical Models of Text Revision. Puerto Rio: Leon University Press.

Badan Standar Nasional Pendidikan (BNSP). 2006. Standar Kompetensi dan Kompetensi Dasar SMP/MTS. Jakarta: Depdikbud.

Barbara. 2010. Essentials of Evidence-Based Academic Interventions. New York: Grow Hill Press.

Bloom, D., Carter, S. P., Christian, B. M., Otto, S., \& Shuart-Faris, N. (2004). Discourse Analysis And The Study Of Language And Literacy Events: $A$ Microethnographic Perspective. Mahwah, NJ: Lawrence Erlbaum.

Bloom in Mira and Hanadi. 2016. Teaching Academic Writing for Advanced Level Grade 10 English. Lebanon: Lebanese University.

Brown, H D. 2000. Teaching by Principles An Interactive Approach to Language Pedagogy (2Ed). San Fransisco: Longman.

Gall, M D.,Gall, J P., and Borg, Walter R. 2003. Educational Research An Introduction( $7 E d)$. New York: Pearson.

Graves, K. 2000. Designing Language Courses: A Guide for Teachers. Canada: Heinle \& Heinle Publisher.

Harmer, J. 1997. The Practice of English Language Teaching. Essex: Longman. 
Haryanti. 2016. Developing Writing Materials for Students of the Eighth Grade of SMP Negeri 3 Tempel. Yogyakarta : Yogyakarta State University.

Hutchinson and Waters. 1987. The Role of Need Analysis in English. Cambridge: Cambridge University Press.

Hibbard, K. \& Wagner, E. A. 2013. Assessing and Teaching Reading Comprehension. New York: Routledge.

McDonough, J. and Shaw, C. 2003. Materials and Method in ELT. New York: Backwell Publishing.

Nunan, D. 1989. Designing Task for the Communicative Classroom. Cambridge: Cambridge University Pers.

Nunan, D. 2004. Task Based Language Teaching.Cambridge: Cambridge University Pers.

Raimes, Ann. 1983. Techniques in Teaching Writing. Oxford: Oxford University Pres.

Raimes in Şükran and Anıl. 2014 Effects of creative writing activities on students' achievement in writing, writing dispositions and attitude to English. Turkey : Pamukkale University

Ray B. 2005. Writing Strategy Instruction. Kansas: Kansas University Press.

Richard. 2011. Handbook of Research on Learning and Instruction. New York: Taylor \& Francis e-Library.

Richards, C J. \& Renandya, A W. 2002. Methodology in Language Teaching. Cambridge: Cambridge University Pers.

Sokolik, M. in Nunan, D (Ed). 2003. Practical English Language Teaching. Singapore: McGrowHill.

Suharto, G. 2005. Penilaian Hasil Belajar Bahasa Inggris. Yogyakarta: Universitas Negeri Yogyakarta.

Tomlinson, B. 1998. Materials Development in Language Teaching. Cambridge: Cambridge University Pers.

Tracie McDonald. 2013. A Writing Handbook for Middle Years Teachers Using the Self-Regulated Strategy Development Model. Manitoba : University of Manitoba. 